\title{
REDISTRIBUTION EFFECTS IN LINEAR ELASTIC ANALYSES OF CONTINUOUS COMPOSITE STEEL-CONCRETE BEAMS ACCORDING TO EUROCODE 4
}

\author{
$U D C 624.012 .46 .042 / .044=111$
}

\section{Svetlana M. Kostić, Biljana Deretić-Stojanović, Saša Stošić}

Faculty of Civil Engineering, University of Belgrade, Serbia

\begin{abstract}
Different analytical methods, with different levels of approximations and accuracy, are available for analysis of continuous composite steel-concrete beams. The Eurocode 4 recommends few simple methods for calculation of creep, shrinkage, cracking of concrete and shear lag effects that are explained in the paper. Through the numerical examples of four continuous composite steel-concrete beams, the proposed methods of analyses are evaluated and compared. Practical recommendations for analysis of this type of girders are formulated.
\end{abstract}

Key words: composite structures, creep, shrinkage, cracking of concrete, shear-lag.

\section{INTRODUCTION}

Composite steel-concrete structures are nowadays widely used for building and bridge structures [1-3]. The reasons lie in a number of benefits obtained by joining two different materials into a single component: higher span width to height ratio, decrease in dead weight and construction time, satisfactory fire performance, etc $[1,3,4]$.

Behavior of composite girders, generally, is highly nonlinear because of nonlinear behavior of each structural part: steel section, reinforced concrete slab and shear connectors. As a consequence, the analysis of composite structures is complex and requires the nonlinear analysis and appropriate computer software [5-10]. However, in order to simplify the design, contemporary design codes, such as Eurocode 4 [11] (EC4), are still mainly based on linear-elastic analysis with some modifications in order to take into account the present nonlinearities $[4,11,12]$.

The aim of this paper is to compare and evaluate results obtained by different methods proposed by EC4 with attention to effects relevant for continuous composite steel-concrete beam design, such as cracking of concrete in area of hogging moments, shear lag effect and concrete viscous deformations.

Received March 22, 2011

Acknowledgement: The first author thanks the Ministry of Science of the Republic of Serbia for financial support under project number TR36046. 


\section{ANALYSIS OF CONTINUOUS COMPOSITE BEAMS}

Continuous composite beams are used in bridges and buildings due to their efficiency referring to load capacity and stiffness. Main advantages of this type of girders over simple beams are lower deformability and higher fundamental frequency of vibrations, on one side, and on the other side, efficient use of resistance capacity of sections under sagging and hogging moments due to moment redistribution [1].

Continuous composite beams are subjected to negative (hogging) bending moments near interior support area. Therefore, in these areas, concrete slab is in tension and cracks, while steel section is under compression. This is an unfavorable situation in design and requires that adequate reinforcement in the slab is provided [13]. Also, cracking of concrete in region of intermediate supports leads to reduced stiffness in these regions and redistribution of flexural rigidity over the beam which has effect on distribution of internal forces and deflections $[3,4,6,14]$.

Besides mentioned cracking of concrete slab effects, the behavior of continuous composite steel-concrete beam is determined by time dependent deformations of concrete $[6$, 10]. Also, non uniform transfer of shear stresses between steel beam and concrete slab, i.e. the shear lag effect, should be considered in the analysis of continuous composite steel-concrete beams. The treatment of each of these effects in building design, according to EC 4, will be explained in the paper.

Other effects, such as slip at shear connectors, buckling of steel sections and method of construction are considered, in the paper, in the following way: composite steel-concrete beams are considered as fully connected - there is no slip at the steel-concrete interface; buckling is considered through the cross-section classification which is based on steel-section classification given in Eurocode 3 [15] (EC3); beams are constructed as propped.

\subsection{Cracking of concrete slab}

EC4 proposes three simple beam methods for an approximate determination of internal forces and moments [3, 4, 11, 13], shown in Fig. 1.
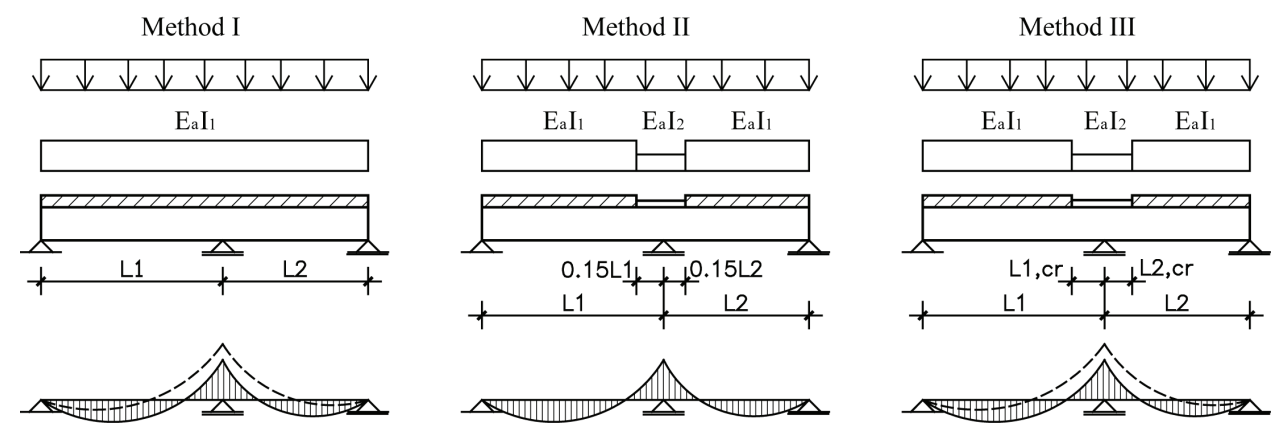

Fig. 1. Three methods for considering cracking of concrete in continuous composite beam analysis

Method I: This analysis is denoted as "uncracked". Internal forces and moments are determined using the flexural rigidity EaI $_{1}$ which is the rigidity of the "uncracked" section 
(Ea is modulus of elasticity of steel, $\mathrm{I}_{1}$ is second moment of area of the effective equivalent steel section assuming that concrete in tension is uncracked). In order to consider cracking of concrete, this way obtained bending moments are reduced for a prescribed percent and a new distribution of bending moments and internal forces is calculated from the equilibrium equations.

Method II: This analysis is denoted as "15\% cracked". The following variation of flexural stiffness over the length of a beam is assumed: within the support range, over $15 \%$ of the field length, flexural rigidity is $\mathrm{EaI}_{2}$ of the cracked section (Ea is modulus elasticity of steel, $\mathrm{I}_{2}$ is second moment of area of the equivalent steel section neglecting concrete in tension but including reinforcement); in the remaining regions, flexural rigidity is the "uncracked" section rigidity, $\mathrm{EaI}_{1}$. Flexural rigidity $\mathrm{EaI}_{2}$ does not include the tension stiffening effect.

Method III: This analysis is denoted as "cracked" and it is an iterative procedure. In the first iteration, internal forces and moments are calculated assuming uncracked concrete slab (stiffness $\mathrm{EaI}_{1}$ ). In the areas where concrete tensile stresses exceed prescribed value ( $2.0 \mathrm{f}_{\mathrm{ctm}}, \mathrm{f}_{\mathrm{ctm}}$ is the mean value of the axial tensile strength of concrete), flexural rigidity is reduced to the value of the cracked section $\left(\mathrm{EaI}_{2}\right)$. The second iteration starts with this new distribution of flexural rigidities, and so on.

EC4 places few restrictions when the three mentioned methods can be used [3]. Method I can be applied to continuous beams for verification of limit states other than fatigue and in the case that second-order effects need not be considered. Additional requirements are that each span is of uniform depth and that no allowance for lateral-torsional buckling is necessary. Percent of redistribution depends on the class of critical cross sections. Also, this method is not allowed for the analysis of bridges. Method II can be applied for continuous composite beams with concrete flanges above the steel section, not prestressed, with all ratios of lengths for all adjacent continuous spans between supports (shorter/longer) at least equal to 0.6 . Method III can be applied without any restrictions, for all ratios of span lengths. Distribution of stiffness obtained this way can be used for both, ultimate and serviceability, limit states. This analysis can also be used for bridges.

\subsection{Creep and shrinkage of concrete}

EC4 [11] accepts linear stress-creep strain relationship and effects of creep and shrinkage of concrete may be taken into account using the following modular ratio between modulus of elasticity of steel and concrete $\mathrm{n}_{\mathrm{L}}$ :

where

$$
n_{L}=n_{0}\left(1+\psi_{L} \varphi_{t}\right)
$$

$n_{0} \quad$ is the modular ratio of steel and concrete (short-term) $\mathrm{E}_{\mathrm{a}} / \mathrm{E}_{\mathrm{cm}}$

$\mathrm{E}_{\mathrm{cm}}$ is the secant modulus of elasticity of concrete for short-term loading, according to Eurocode 2 [16] (EC2)

$\varphi_{t} \quad$ is the creep coefficient according to EC2

$\psi_{L} \quad$ is the creep multiplier dependent on the type of loading and can be taken as 1.1 for permanent loading, 0.55 for primary and secondary effects of shrinkage and 1.5 for prestressing by imposed deformations. 
The proposed modular ration $\mathrm{n}_{\mathrm{L}}$ is based on the Effective Modulus Method and the corresponding effective modulus for concrete is [17]:

$$
E_{c, \text { eff }}^{\prime}=\frac{E_{c m}}{1+\psi_{L} \varphi_{t}} .
$$

Therefore, the analysis for long term effects is the same as for short term effects, but instead of modulus of elasticity of concrete $E_{c m}$, the effective modulus $E_{c, \text { eff }}^{\prime}$ should be used. However, EC4 allows that, for simplification, in structures for buildings, for verifications of ultimate limit states, the unique modular ratio $n=2 n_{0}$ can be used for both longterm and short-term loadings. This simplification is limited to buildings not mainly intended for storage and not pre-stressed by controlled imposed deformations. Also, in analysis of structures for buildings, the shrinkage effects can be neglected for verifications of ultimate limit states and, if not significant, for serviceability limit states.

\subsection{Shear lag effect}

Transfer of shear stresses between steel beam and concrete slab fully mobilizes the slab only if the width of slab between adjacent beams is not too great. The induced stress distribution is not uniform and this is known as the shear lag effect. EC4, as well as other design codes, treats this problem considering an isolated beam having a width $\left(b_{\text {eff }}\right)$ so that the behavior of the associated T-beam closely approximates that of the slab/steel element system (Fig. 2) [18, 19]. It is known as "effective width" approach. The following expressions are proposed for effective widths [11]:

$$
b_{e f f}=b_{0}+b_{e 1}+b_{e 2}, b_{e i}=\min \left\{L_{e} / 8, b_{i}\right\}
$$

where $\mathrm{L}_{\mathrm{e}}$ is defined as the maximum distance between points of contra flexure and recommended values are given in Fig. 3.

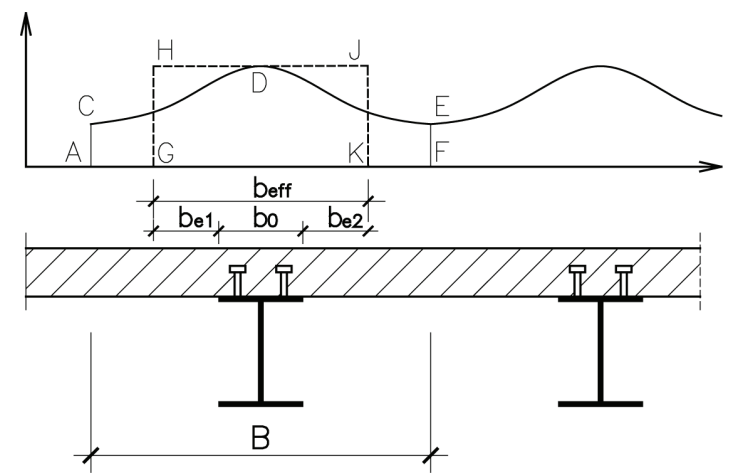

Fig. 2. Effective width and nonuniform stress distribution 


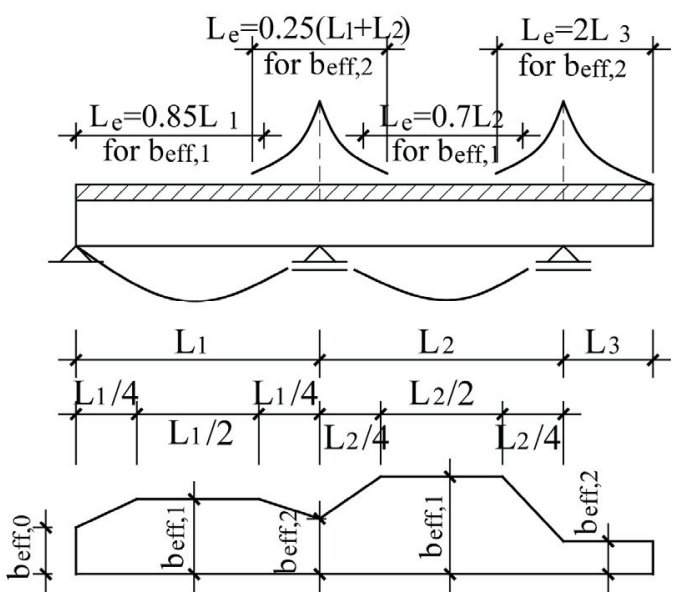

Fig. 3. Equivalent spans, for effective width of concrete flange according to EC4 [11]

\section{EVALUATION STUDY}

In order to compare results obtained with different, previously described, EC4 methods for analysis of continuous composite beams in buildings, four girders were numerically tested by a computer program "Kontinualac" $[3,4]$. The program is based on finite element method. The used finite element is linear elastic with two nodes and three unknowns at each node, Fig. 4. Its cross section, composed of steel section and concrete slab, may vary along its length, as shown in Fig. 5. When element has more than one type of cross-section it is divided into "regions". Inside a region, steel part of the element is constant while width of concrete slab may change in a linear way. Therefore, it is possible to model beam with different linearly variable effective width, as suggested by EC4 [11] for modeling the shear lag effect.

Also, the element has its "cracked lengths", $\mathrm{L}_{1}$ and $\mathrm{L}_{2}$ (Fig. 6) where it is assumed that concrete slab is cracked and that flexural rigidity is $\mathrm{EaI}_{2}$. The cracked lengths can be given by the user or can be determined from the condition that stress in the top concrete fiber exceeds two times (or by some other number) value of the axial tensile strength of concrete. This way, the "15\% cracked" analysis, as well as, the "cracked" analysis can be performed.

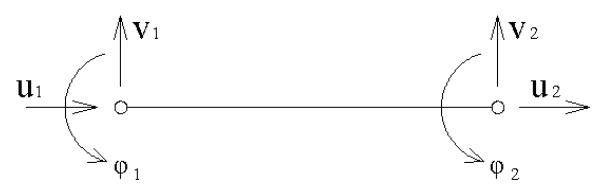

Fig. 4. Finite element and unknowns 

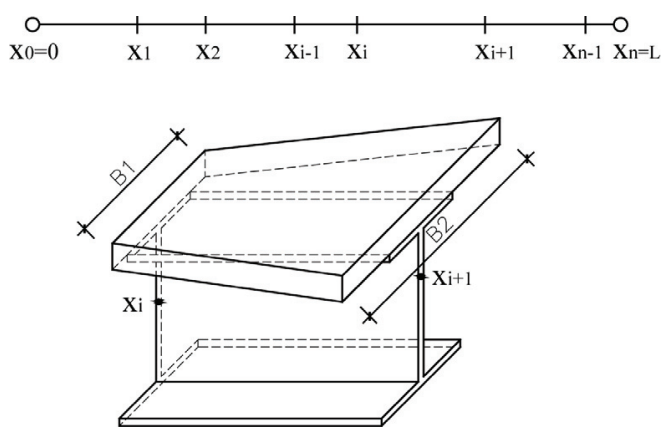

Fig. 5. Finite element with division into regions and one region

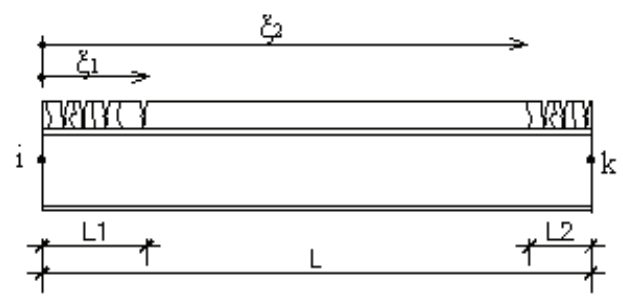

Fig. 6. Cracked lengths of the finite element

\subsection{Set of continuous beams}

Four composite continuous girders with spans and loadings that are common in building structures (not for bridges) are studied. A larger numerical study can be found in [3]. A brief description of girders follows.

Type 1: Two span continuous composite beam with span lengths $\mathrm{L}_{1}=10 \mathrm{~m}$ and $\mathrm{L}_{2}=10 \mathrm{~m}$, Fig. 7. Loading: dead load $\mathrm{g}=16 \mathrm{kN} / \mathrm{m}$ and live load $\mathrm{p}=24 \mathrm{kN} / \mathrm{m}$.
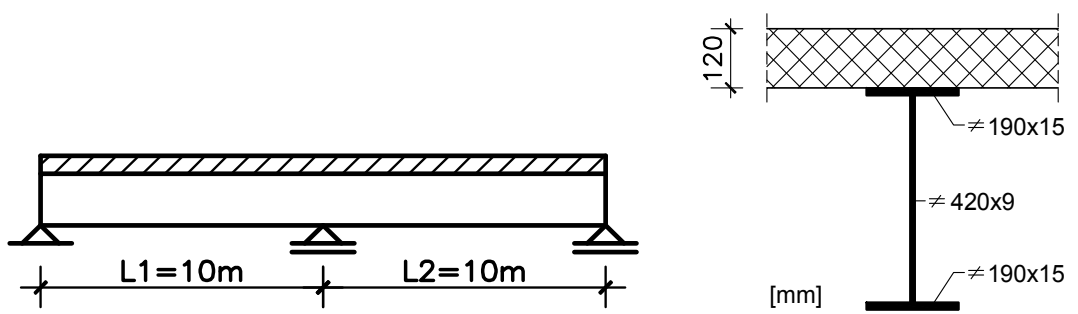

Fig. 7. Girder type 1 and its cross section

- Spacing between adjacent beams: $5 \mathrm{~m}$

- Thickness of concrete slab: $0.12 \mathrm{~m}$

- Reinforcement: $\varnothing 10 / 12.5 \mathrm{~cm}$

- Steel S235, $\mathrm{f}_{\mathrm{y}}=23.5 \mathrm{kN} / \mathrm{cm}^{2}, \mathrm{E}_{\mathrm{a}}=210 \mathrm{kN} / \mathrm{mm}^{2}$

- Reinforcement $\mathrm{f}_{\text {sk }}=42 \mathrm{kN} / \mathrm{cm}^{2}, \mathrm{E}_{\mathrm{s}}=210 \mathrm{kN} / \mathrm{mm}^{2}$

- Concrete $\mathrm{C} 25 / 30, \mathrm{f}_{\mathrm{ck}}=2.5 \mathrm{kN} / \mathrm{cm}^{2}, \mathrm{E}_{\mathrm{cm}}=31 \mathrm{kN} / \mathrm{mm}^{2}$ 
Type 2: Two span continuous composite beam with span lengths $\mathrm{L}_{1}=12 \mathrm{~m}$ and $\mathrm{L}_{2}=12 \mathrm{~m}$, Fig. 8. Loading: dead load $\mathrm{g}=17.1 \mathrm{kN} / \mathrm{m}$ and live load $\mathrm{p}=25.6 \mathrm{kN} / \mathrm{m}$.
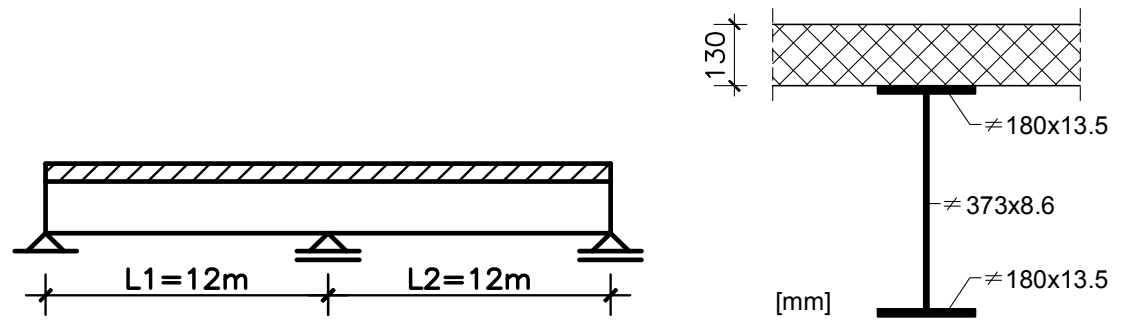

Fig. 8. Girder type 2 and its cross section

- Spacing between adjacent beams: $3 \mathrm{~m}$

- Thickness of concrete slab: $0.13 \mathrm{~m}$

- Reinforcement: $\varnothing 12 / 15 \mathrm{~cm}$

- Steel S355, $\mathrm{f}_{\mathrm{y}}=35.5 \mathrm{kN} / \mathrm{cm}^{2}, \mathrm{E}_{\mathrm{a}}=210 \mathrm{kN} / \mathrm{mm}^{2}$

- Reinforcement $\mathrm{f}_{\mathrm{sk}}=50 \mathrm{kN} / \mathrm{cm}^{2}, \mathrm{E}_{\mathrm{s}}=210 \mathrm{kN} / \mathrm{mm}^{2}$

- Concrete $\mathrm{C} 25 / 30, \mathrm{f}_{\mathrm{ck}}=2.5 \mathrm{kN} / \mathrm{cm}^{2}, \mathrm{E}_{\mathrm{cm}}=31 \mathrm{kN} / \mathrm{mm}^{2}$

Type 3: Two span continuous composite beam with span lengths $\mathrm{L}_{1}=9.5 \mathrm{~m}$ and $\mathrm{L}_{2}=9.5 \mathrm{~m}$, Fig. 9. Loading: dead load $\mathrm{g}=21.8 \mathrm{kN} / \mathrm{m}$ and live load $\mathrm{p}=20 \mathrm{kN} / \mathrm{m}$.
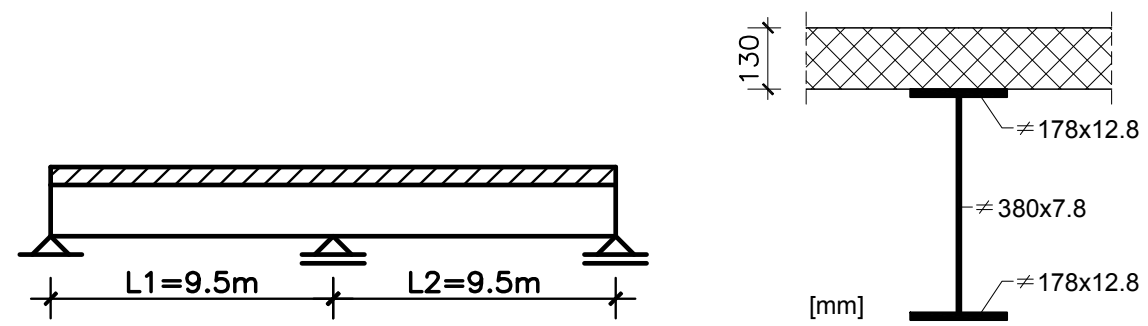

Fig. 9. Girder type 3 and its cross section

- Spacing between adjacent beams: $4 \mathrm{~m}$

- Thickness of concrete slab: $0.13 \mathrm{~m}$

- Reinforcement: $\varnothing 8 / 10 \mathrm{~cm}$

- Steel S355, $\mathrm{f}_{\mathrm{y}}=35.5 \mathrm{kN} / \mathrm{cm}^{2}, \mathrm{E}_{\mathrm{a}}=210 \mathrm{kN} / \mathrm{mm}^{2}$

- Reinforcement $\mathrm{f}_{\mathrm{sk}}=46 \mathrm{kN} / \mathrm{cm}^{2}, \mathrm{E}_{\mathrm{s}}=210 \mathrm{kN} / \mathrm{mm}^{2}$

- Concrete $\mathrm{C} 25 / 30, \mathrm{f}_{\mathrm{ck}}=2.5 \mathrm{kN} / \mathrm{cm}^{2}, \mathrm{E}_{\mathrm{cm}}=31 \mathrm{kN} / \mathrm{mm}^{2}$

Type 4: Three span continuous composite beam with span lengths $\mathrm{L}_{1}=9 \mathrm{~m}, \mathrm{~L}_{2}=9 \mathrm{~m}$ and $\mathrm{L}_{3}=9 \mathrm{~m}$, Fig. 10 . Loading: dead load $\mathrm{g}=22 \mathrm{kN} / \mathrm{m}$ and live load $\mathrm{p}=25 \mathrm{kN} / \mathrm{m}$. 


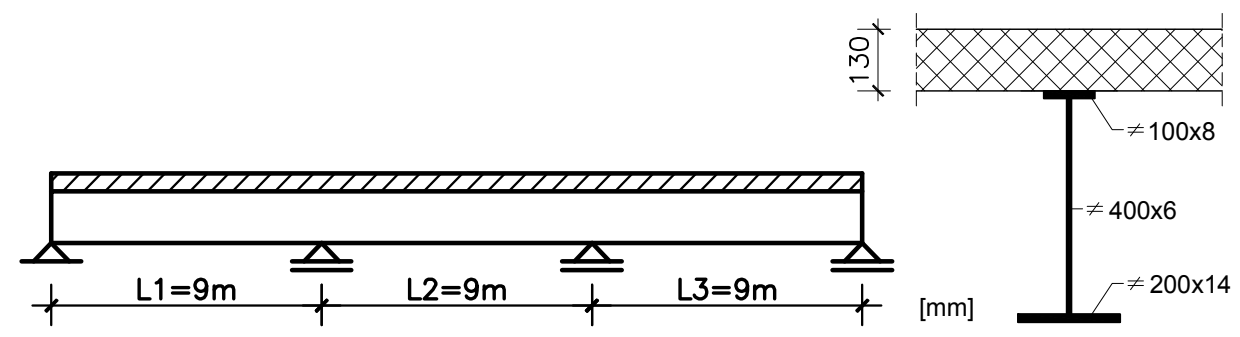

Fig. 10. Girder type 4 and its cross section

- Spacing between adjacent beams: $3 \mathrm{~m}$

- Thickness of concrete slab: $0.13 \mathrm{~m}$

- Reinforcement: $\varnothing 12 / 10 \mathrm{~cm}$

- Steel S235, $\mathrm{f}_{\mathrm{y}}=23.5 \mathrm{kN} / \mathrm{cm}^{2}, \mathrm{E}_{\mathrm{a}}=210 \mathrm{kN} / \mathrm{mm}^{2}$

- Reinforcement $\mathrm{f}_{\mathrm{sk}}=42 \mathrm{kN} / \mathrm{cm}^{2}, \mathrm{E}_{\mathrm{s}}=210 \mathrm{kN} / \mathrm{mm}^{2}$

- Concrete $\mathrm{C} 25 / 30, \mathrm{f}_{\mathrm{ck}}=2.5 \mathrm{kN} / \mathrm{cm}^{2}, \mathrm{E}_{\mathrm{cm}}=31 \mathrm{kN} / \mathrm{mm}^{2}$

\subsection{Type of analyses}

The main aim of this study is to compare results obtained by different linear-elastic analyses proposed by EC4, considering primary cracking of concrete, creep and shrinkage and shear-lag effects. As noted before, the study is limited to girders applied in buildings (office and resident), not mainly intended for storage, not pre-stressed by controlled deformations and constructed as propped. The following analyses, suitable for ultimate limit states (ULS) according to EC4, are conducted:

Analysis 1: The effects of shrinkage are neglected. Creep effects are taken into account by using the same modular ratio $n=2 \cdot n_{0}$ for both short-term and long-term loadings. Variations of this method, related to cracking of concrete and shear lag effects, are explained below:

a) Constant effective width assumed over each span, "uncracked" analysis is applied;

b) Constant effective width assumed over each span, "15\% cracked" analysis is applied;

c) Constant effective width assumed over each span, "cracked" analysis is applied;

d) Distribution of effective widths according to EC4 is assumed, "uncracked" analysis is applied;

e) Distribution of effective widths according to EC4 is assumed, " $15 \%$ cracked" analysis is applied;

f) Distribution of effective widths according to EC4 is assumed, "cracked" analysis is applied.

This analysis 1 is the simplest analysis allowed by EC4 for ULS checks.

Analysis 2: Separate analyses for long-term (using modular ratio $\mathrm{n}_{\mathrm{L}}$ ) and short term (using $\mathrm{n}_{0}$ ) loadings are performed. Shrinkage effects are neglected. The same variation of the analysis a), b), c), d), e) and f) as explained above, are performed.

The following analyses, suitable for serviceability limit states (SLS) according to EC4, are conducted: 
Analysis 3: Effects of shrinkage are neglected. Creep effects are taken into account by using two different modular ratios: $\mathrm{n}_{0}$ and $\mathrm{n}_{\mathrm{L}}$. Cracking of concrete is included and, therefore, only variants of this analysis denoted as b), c), e) and f) are performed. This is the simplest analysis allowed by EC4 for SLS checks.

Analyses 4: Separate analysis for long-term $\left(\mathrm{n}_{\mathrm{L}}\right)$ and short-term $\left(\mathrm{n}_{0}\right)$ loadings are performed. Shrinkage effects are calculated using the modular ratio $\mathrm{n}_{\mathrm{s}}$. Only variants of the analysis with constant effective widths, b) and c), are performed.

\subsection{Results}

Considering results of analyses 1 and 2 that are adequate for ULS design, the percent of redistribution of bending moments that corresponds to b) and c) analyses relatively to a) analysis, and also, redistribution that corresponds to e) and f) analyses relatively to d) analysis are calculated. These results are graphically shown in Fig. 11 and Fig. 12.

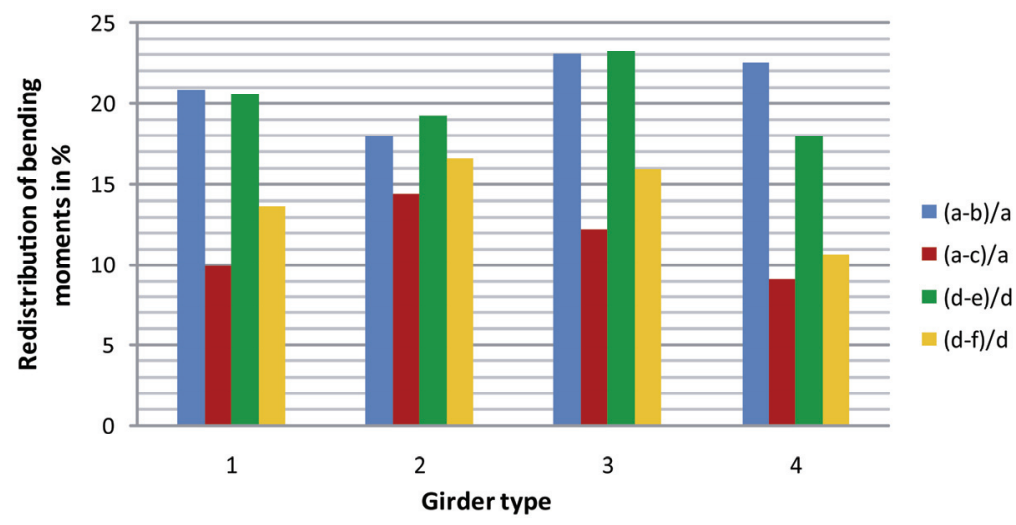

Fig. 11. Analysis 1: percent of redistribution of "15\% cracked" and "cracked" analyses relatively to "uncracked" analysis

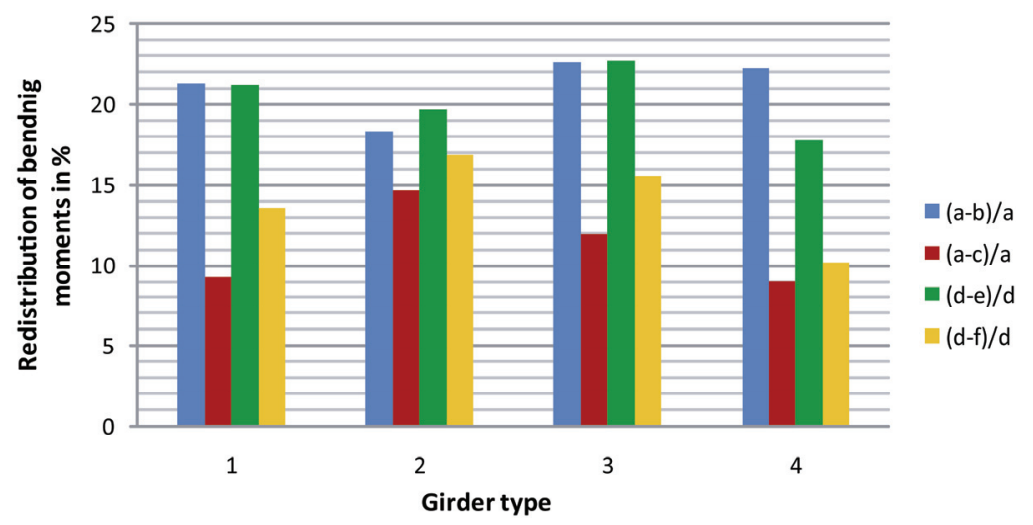

Fig. 12. Analysis 2: percent of redistribution of "15\% cracked" and "cracked" analyses relatively to "uncracked" analysis 
As can be seen from these figures, the results for both analyses (1 and 2) follow the same "trend" and do not depend on the way the creep is being considered (by using the same modular ratio or by separating long- and short-term loadings and using two different modular ratios). Also, the percent of redistributions obtained by "15\%" cracked analysis relatively to "uncracked" analysis are $20 \pm 3 \%$, while redistributions obtained by "cracked" analysis are lower, from 9 to $17 \%$. This can be explained by the fact that the zone of cracked concrete determined from "cracked" analysis was much smaller than the lengths assumed in $15 \%$ cracked analysis (see Table 1). If results of "cracked" analysis are considered as closer to the exact solution, it means that when a girder is analyzed by " $15 \%$ cracked" analysis and then maximal allowed percent of redistribution to hogging moments considering class of cross-section is applied, this way obtained hogging moments will be smaller than one obtained by "cracked" analysis with maximal allowed percent of redistribution. This may be dangerous in cases when redistribution is less than assumed, since local instabilities in the steel web or compression flange in a region of negative moment may appear prematurely. Results of the "uncracked" analysis with maximal redistribution applied are much closer to the results of "cracked" analysis with maximal allowed percent of redistribution. Thus, in the case that actual cracked lengths differ significantly from the $15 \%$ of span length, it is advisable to apply either simple "uncracked" analysis or "cracked" analysis.

Table 1. Lengths of cracked concrete zone at internal support: analysis 1, analysis 2 and "15\% cracked" analysis in (m)

\begin{tabular}{cccccc}
\hline \multirow{2}{*}{ Girder type: } & \multicolumn{2}{c}{ Analysis 1 } & \multicolumn{2}{c}{ Analysis 2 } & \multirow{2}{1}{\begin{tabular}{c}
$15 \%$ cracked \\
\cline { 2 - 5 }$(\mathrm{m})$
\end{tabular}} \\
\hline 1 & 0.78 & $\mathrm{f})(\mathrm{m})$ & $\mathrm{c})(\mathrm{m})$ & $\mathrm{f})(\mathrm{m})$ & \\
2 & 2.13 & 2.34 & 0.68 & 1.12 & 3.00 \\
3 & 0.82 & 1.18 & 0.82 & 2.30 & 3.60 \\
4 & 0.52 & 0.90 & 0.51 & 0.84 & 2.85 \\
\hline
\end{tabular}

Related to the effective width distribution, the study has shown that there is a small sensitivity of the results to the effective width variation over the girder length. The largest variation is obtained between results of "cracked" analysis since, due to presence of cracked lengths, the differences in flexural stiffness are the greatest. However, even then, the results do not differ by more than $7 \%$. The difference in peak hogging bending moments calculated by corresponding pairs of the analysis - a) and d); b) and e); c) and f) are given in Tables 2-3.

Table 2. Analysis 1: difference in peak hogging bending moments

\begin{tabular}{cccc}
\hline Girder type: & $|\mathrm{a}-\mathrm{d}| / \mathrm{a}[\%]$ & $|\mathrm{b}-\mathrm{e}| / \mathrm{b}[\%]$ & $|\mathrm{c}-\mathrm{f}| \mathrm{c}[\%]$ \\
\hline 1 & 2.78 & 2.49 & 6.85 \\
2 & 2.51 & 4.06 & 5.00 \\
3 & 2.69 & 2.85 & 6.92 \\
4 & 1.31 & 4.52 & 3.05 \\
\hline
\end{tabular}


Table 3. Analysis 2: difference in peak hogging bending moments

\begin{tabular}{cccc}
\hline Girder type: & $|\mathrm{a}-\mathrm{d}| / \mathrm{a}[\%]$ & $|\mathrm{b}-\mathrm{e}| / \mathrm{b}[\%]$ & $|\mathrm{c}-\mathrm{f}| / \mathrm{c}[\%]$ \\
\hline 1 & 2.57 & 2.49 & 7.16 \\
2 & 2.51 & 4.06 & 5.04 \\
3 & 2.74 & 2.83 & 6.78 \\
4 & 1.21 & 4.47 & 2.50 \\
\hline
\end{tabular}

Considering the creep effect and the analyses when short and long-term loadings are considered by using the same modular ratio, on one side, and on the other side by using the two different modular ratios, the study has shown that it is fully justified to simplify the analysis and use the same modular ratio for all loadings. The obtained peak hogging bending moments, shown for $\mathrm{f}$ ) analyses in Table 4 , differ by less than $1 \%$.

Table 4. Creep effect: difference in peak hogging bending moments calculated by analysis $1 \mathrm{f}$ ) and analysis $2 \mathrm{f}$ )

\begin{tabular}{cc}
\hline Girder type: & $|\mathrm{A} 1 \mathrm{f}-\mathrm{A} 2 \mathrm{f}| / \mathrm{A} 1 \mathrm{f}[\%]$ \\
\hline 1 & 0.33 \\
2 & 0.36 \\
3 & 0.37 \\
4 & 0.63 \\
\hline
\end{tabular}

Related to SLS design, deflections calculated using different methods were compared. Results are shown in Table 5. Since that calculated cracked lengths are smaller than 15\% of the span length, a girder in the " $15 \%$ cracked" analysis is more flexible and has higher maximal deflections. Therefore, the results of "15\% cracked" analysis are on the safe side. Also, it can be noticed that by including shrinkage effects, maximal deflections increase approximately about $20 \%$ (analyses 3 and 4 ). Therefore, in the case that deflection requirements govern the design, this effect may be important.

Table 5. Maximal calculated deflections, Analyses 3 and 4

\begin{tabular}{ccccc}
\hline \multirow{2}{*}{ Girder type: } & \multicolumn{2}{c}{ Analysis 3 } & \multicolumn{2}{c}{ Analysis 4 } \\
\cline { 2 - 5 } & b) $(\mathrm{m})$ & $\mathrm{c})(\mathrm{m})$ & b) $(\mathrm{m})$ & $\mathrm{c})(\mathrm{m})$ \\
\hline 1 & 0,018 & 0,017 & 0,022 & 0,020 \\
2 & 0,034 & 0,034 & 0,041 & 0,039 \\
3 & 0,021 & 0,020 & 0,026 & 0,023 \\
4 & 0,019 & 0,018 & 0,023 & 0,021 \\
\hline
\end{tabular}

\section{RECOMMENDATIONS FOR ANALYSIS}

Considering all presented analyses and additional results given in [3, 4], the following practical recommendations for design of steel-concrete composite beams are formulated. These recommendations are made for beams in office or resident buildings, not mainly intended for storage, not pre-stressed by controlled deformations and constructed as propped, with spans commonly within the range from 7 to $12 \mathrm{~m}$. Concrete slab is made of normal-weight concrete, class C25/30 and class of steel section is S235 or S355. 
ULS design:

- Application of "15\% cracked" analysis should be followed by calculation of zone in which concrete is cracked at the intermediate support area. In the case that these lengths significantly differ from the one proposed by the "15\% cracked" analysis, the use of this method may not be fully legitimate and it is recommended that more accurate "cracked" analysis or simple "uncracked" analysis is used.

- Distrubition of effective widths along beam's length has little effect on redistribution of sectional forces. It may be justified to use variable distribution of widths of concrete slab if "cracked" analysis is applied, while for other types of analyses ("uncracked" and "15\% cracked") differences in results are insignificant. Therefore, in these cases, the use of simplified analysis with uniform distribution of width of concrete slab is justified in ordinary design practice.

- It is fully reasonable to consider creep of concrete effects by using the same modular ratio for short and long-term loadings.

SLS design - maximal deflections:

- Use of simplified "15\% cracked" analysis for SLS design mostly gives results that are on the safe side, and therefore this method is recommended for calculation of maximal deflections.

- Shrinkage of concrete may have significant influence on deflections, since increase them by $20 \%$. Therefore, in cases when maximal deflections govern the design, this effect should be considered.

\section{CONCLUSION}

EC4 gives guidelines for analysis of steel-concrete composite structures which are based on modified linear-elastic analysis in order to account all effects relevant for design. In this paper, analyses appropriate for design of continuous composite steel-concrete beams are described and conducted on several examples. In addition, the results obtained by different methods are studied. Finally, practical recommendations for design of continuous composite steel-concrete beams are formulated.

\section{REFERENCES}

1. R.P. Johnson, Composite Structures of Steel and Concrete: Beams, slabs, columns, and frames for Buildings, 3rd ed., Blackwell Publishing, Oxford, 2004.

2. I.M. Miličić, Lj.M. Vlajić, R. J. Folić, "Numeričko modeliranje i simulacija - eksperimentalno-teorijske analize spregnute tavanice pri statičkom dejstvu", Materijali i konstrukcije, vol. 51, br. 3, str. 51-60, 2008.

3. S. Seizović, "Analysis of Continuous Composite Steel and Concrete Beam", Master thesis, Faculty of Civil Engineering, University of Belgrade, 2006.

4. S. Kostić, B. Deretić-Stojanović, Cracking of concrete effects in continuous composite beam analysis according to EC4, 2nd International Congress of Serbian Society of Mechanics, Palić (Subotica), 1-5 June 2009.

5. Z. Bonić, T. Vacev, V. Prolović, M. Mijalković, P. Dančević, "Mathematical modeling of materially nonlinear problems in structural analyses (Part II - application in contemporary software)", Facta Universitatis, Series: Architecture and Civil Engineering, Vol. 8, No 2, 2010, pp. 201-210.

6. R. I. Gilbert, M. A. Bradford, "Time-dependent behavior of continuous composite beams at service loads", Journal of Structural Engineering, Vol. 121, No 2, 1995, pp. 319-327. 
7. J. Nie, C.S. Cai, "Steel-Concrete Composite Beams Considering Shear Slip Effects", Journal of Structural Engineering, Vol. 129, No 4, 2003, pp. 495-506.

8. Ayoub, "A force-based model for composite steel-concrete beams with partial interaction", Journal of Constructional Steel Research, No 61, 2005, pp. 387-414.

9. Faella, E. Martinelli, E. Nigro, "Shear Connection Nonlinearity and Deflections of Steel-Concrete Composite Beams: A Simplified Method", Journal of Structural Engineering, Vol. 129, No 1, 2003, pp. 12-20.

10. M. Fragiacomo, C. Amadio, L. Macorini, "Finite-Element Model for Collapse and Long-Term Analysis of Steel-Concrete Composite Beams", Journal of Structural Engineering, Vol. 130, No 3, 2004, pp. 489-497.

11. EN 1994-1-1: Eurocode 4: Design of composite steel and concrete structures - Part 1-1: General rules and rules for buildings, CEN, 2004.

12. S. Ranković, D. Drenić, "Static strength of the shear connectors in steel-concrete composite beams regulations and research analysis", Facta Universitatis, Series: Architecture and Civil Engineering, Vol. 2, No 4, 2002, pp. 251-259.

13. R.P. Johnson and D. Anderson, Designers' Guide to EN 1994-1-1: Eurocode 4: Design of Composite Steel and Concrete Structures, Part 1-1: General Rules and Rules for Buildings, Thomas Telford Publishing, London, 2004.

14. D. A. Nethercot, T. Q. Li, B. S. Choo, "Required Rotations and Moment Redistribution for Composite Frames and Continuous Beams", Journal of Constructional Steel Research, No 35, 1995, pp. 121-163.

15. EN 1993-1-1: Eurocode 3: Design of composite steel structures - Part 1-1: General rules and rules for buildings, CEN, 2005.

16. EN 1992-1-1: Eurocode 2: Design of concrete structures - Part 1-1: General rules and rules for buildings, CEN, 2004.

17. S. Kostić, B. Deretić-Stojanović, Proračun skupljanja i tečenja pri analizi spregnutih kontinualnih nosača prema EC4, GNP 2010 - Treći internacionalni naučno-stručni skup: Građevinarstvo - nauka i praksa, Žabljak, 15-19. Februara 2010.

18. M. Chiewanichakorn, A. J. Aref, S. S. Chen, II-S. Ahn, "Effective Flange Width Definition for SteelConcrete Composite Bridge Girder", Journal of Structural Engineering, Vol. 130, No 12, 2004, pp. 2016-2031.

19. L. Macorini, M. Fragiacomo, C. Amadio, B.A. Izzuddin, "Long-term analysis of steel-concrete composite beams: FE modeling for effective width evaluation", Engineering Structures, No 28, 2006, pp. 1110-1121.

\section{REDISTRIBUCIJA UTICAJA U LINEARNO ELASTIČNOJ ANALIZI SPREGNUTIH KONTINUALNIH NOSAČA OD ČELIKA I BETONA PREMA EVROKODU 4}

\section{Svetlana M. Kostić, Biljana Deretić-Stojanović, Saša Stošić}

Za analizu spregnutih kontinualnih nosača od čelika i betona postoje različite analitičke metode, različitog stepena tačnosti. Evrokod 4 dozvoljava i preporučuje nekoliko jednostavnih metoda kojima se u proračun uvode nelinearni efekti kao što su skupljanje i tečenje betona, ispicalost betonske ploče $i$ shear-lag efekat, $i$ one su objašnjene u radu. Kroz numeričku analizu četiri spregnuta kontinualna nosača ove metode su upoređene $i$ date su praktične preporuke za analizu ove grupe nosača.

Key words: spregnute konstrukcije, tečenje, skupljanje, ispucalost betona, shear-lag. 